\title{
HAJI DAN STATUS SOSIAL: Studi Tentang Simbol Agama di Kalangan Masyarakat Muslim
}

\author{
M. Zainuddin \\ UIN Maulana Malik Ibrahim Malang \\ email: aldin_uin@yahoo.com
}

\begin{abstract}
Religion as a fact and history has symbolic and sociological dimensions as a structure of abstract realm regardless of space and time. Pilgrimage substantially contains humanity values, such as the doctrines of equality, the necessity to preserve life, property, and honor of others, a ban of oppressing or exploiting the weak people, either economically or others. For example, releasing daily wear and changing it with ihram wear has meaning to erase the social gaps between the rich and the poor. That is the ideal teaching of pilgrimage making one aware that he is a social human. This paper is sociologically intended to see the phenomenon of pilgrimage in the Muslim society of Indonesia, especially in Java. The study showed that the pilgrimage of the majority of Indonesian Muslim is loaded with social attributes. Although the pilgrim is a part of the religion pillars, it has been utilized by the local ruling elite as a political resource or a mean to establish power legitimacy.
\end{abstract}

Agama sebagai fakta dan sejarah memiliki dimensi simbolis dan sosiologis sebagai struktur sebuah makna yang berada pada ranah abstrak, terlepas dari ruang dan waktu. Ibadah haji secara substansial mengandung nilai-nilai kemanusiaan, seperti ajaran tentang: persamaan, keharusan memelihara jiwa, harta, dan kehormatan orang lain, larangan melakukan penindasan atau pemerasan terhadap kaum lemah, baik di bidang ekonomi maupun bidang-bidang lain. Misalnya, menanggalkan pakaian yang dipakai sehari-hari dan menggantinya dengan baju ihram untuk menghapus kesenjangan sosial antara kaya dan miskin. Itulah harapan ideal ajaran haji untuk membuat pelakunya menyadari bahwa ia adalah makhluk sosial. Tulisan ini bertujuan untuk mengungkap fenomena 
haji dalam masyarakat Indonesia, terutama di Jawa, secara sosiologis. Studi ini menunjukkan bahwa ibadah haji yang dilakukan oleh mayoritas muslim Indonesia dipenuhi dengan atribut-atribut sosial. Meski merupakan salah satu pilar agama, ibadah haji telah digunakan elit penguasa lokal sebagai sumberdaya politik atau alat membangun legitimasi kekuasaan.

Keyword: hajj, social status

\section{Pendahuluan}

Pada sebagian masyarakat Islam tertentu, ibadah haji merupakan salah satu ibadah yang menempati kedudukan istimewa dalam kehidupan keagamaannya. Hal demikian bisa dibuktikan melalui kenyataan akan besarnya minat masyarakat untuk melaksanakan ibadah haji dalam setiap tahunnya. Data statistik yang ada pada kantor urusan haji menunjukkan peningkatan yang berarti setiap tahunnya.

Ibadah haji dianggap sebagai ritus kehidupan muslim Indonesia (Vandenbregt, 1991: 45). Melalui etos sosial dan perilaku keagamaan, ibadah haji sering diidentifikasikan sebagai upacara transisi yang mengakhiri kurun waktu kehidupan tertentu menuju kurun waktu yang baru. Tipologi Cliford Geert membagi ritus kehidupan haji ke dalam tiga kategori: kategori anak muda, kategori usia lanjut, dan kategori pegawai negeri pensiunan.

Pertama, bagi anak muda, ibadah haji menjadi penutup ideal setelah pendidikan di pesantren dan sekaligus akhir masa remaja. Jika seorang remaja sudah berhaji berarti ia telah memasuki status baru, dan dipertegas dengan nama baru yang diperoleh dari tanah suci Makkah plus segala atribut yang disandangnya. Kedua, haji bagi usia lanjut. Bagi orang berusia lanjut, ibadah haji dianggap sebagai akhir dari perjalanan hidup untuk mengabdikan diri pada kehidupan agama dan menutup kurun waktu kehidupan yang penting. Ketiga, haji pensiunan, yaitu melaksanakan ibadah haji setelah pensiun dari pegawai negeri. Bagi mereka, ibadah haji pun dianggap sebagai akhir suatu kurun waktu dan awal tahap kehidupan baru.

Fakta mengenai besarnya minat untuk berhaji tersebut telah menarik perhatian tersendiri, mengingat di satu sisi haji adalah cabang ibadah yang sangat bergantung pada kemampuan finansial $(\mathrm{ONH})$ yang relatif mahal, dan secara umum ibadah tersebut hanya bisa dijangkau oleh mereka yang mampu, yang dalam bahasa agama disebut istitha'ah.

Fenomena menarik dari pengalaman ibadah haji di atas adalah mengapa masyarakat mampu melaksanakan ibadah haji yang tidak hanya sekali, tetapi 
beberapa kali? Adakah doktrin yang membentuk pola pikir, sikap, maupun gaya hidup mereka? Ataukah karena haji secara sosiologis telah dipandang sebagai ibadah yang sarat dengan atribut sosial mereka? Tulisan ini ingin mengungkap relasi antara simbol agama, dalam hal ini ibadah haji, dengan status sosial di kalangan masyarakat muslim Indonesia.

\section{Manusia dan Realitas Simbolik}

Agama sebagai fakta dan sejarah memiliki dimensi simbolis atau mitis dan sosiologis. Dimensi simbolis atau mitis mengandung arti bahwa agama merupakan struktur sebuah makna (meaning structure) yang berada pada ranah abstrak, terlepas dari ruang dan waktu. Melalui struktur makna seperti ini maka mode pemahaman (mode of self-understanding) digagas dan diciptakan melalui berbagai kegiatan penafsiran (hermeneutics) atas ajaran. Dalam kegiatan ini penciptaan dan penafsiran atas simbol-simbol dan metafor yang ada kemudian dirumuskan serta diterapkan dalam tindakan aktual (Hikam, 2002: 1).

Simbol agama bagi masyarakat muslim Jawa memang begitu berarti. Tidak hanya dalam ranah privat, tetapi juga dalam ranah publik, tidak hanya bagi kalangan muslim awam (populis), tetapi juga muslim elit (penguasa). Pada muslim elit, penggunaan simbol agama sangat efektif bagi pengakuan (legitimasi) kekuasaannya. Penguasa (Presiden, Menteri dan pejabat tinggi yang lain) seringkali memanfaatkan simbol agama tersebut dalam melancarkan program-programnya. Banyak "muslim bukan santri" yang segera menunaikan ibadah haji setelah dilantik menjadi pejabat penting di suatu pemerintahan. Jargon-jargon agama juga banyak digunakan dalam melegitimasi program dan kekuasaannya.

Pada ranah publik, agama dijadikan oleh elit penguasa lokal sebagai sumberdaya politik atau sarana membangun legitimasi kekuasaan dengan berbagai manifestasi sesuai ritme dan konteks sosial yang tengah dihadapi (Maliki, 2002: 356, 360). Kesemarakan agama, termasuk pesona santrinisasi priyayi dengan banyaknya simbol seperti sajadah, label haji, dan seterusnya, juga lebih berorientasi kekuasaan dari pada pencerahan spiritual. Agama (baca: Islam) tersandera oleh kepentingan elit penguasa.

Pemikiran simbolik merupakan bagian esensial manusia dan pemikiran tersebut mendahului bahasa dan pemikiran deskriptif (Eliade dalam Morris, 2003: 271). Simbol mengungkapkan aspek-aspek terdalam dari kenyataan yang tidak terjangkau oleh alat pengenal lain. Gambar (image), simbol dan mitos memenuhi fungsi mengungkapkan masalah modalitas yang paling rahasia 
(Minsarwati, 2002: 26).

"Manusia merupakan animal symbolicum. Dengan kemahiran komunikasi simbolik, seluruh kehidupan manusia ditransformasikan secara radikal. Jika dibandingkan dengan binatang, manusia tidak semata-mata hidup dalam realitas yang lebih luas, melainkan lebih dari itu, ia ada dalam "dimensi realitas baru”. Representasi simbolik merupakan fungsi sentral kesadaran manusia dan menjadi dasar bagi pemahaman kita tentang seluruh kehidupan manusia, termasuk: bahasa, seni, sejarah, agama dan sebagainya. Karena universalitasnya, simbolisme kemudian dianggap oleh Cassirer, sebagai "biji yang terbuka" bagi pemahaman budaya manusia.” (Cassirer dalam Morris, 2003: 271).

Baik Levi-Strauss maupun Cassirer berpendapat bahwa pengetahuan manusia pada dasarnya adalah simbolik. Perbedaan antara agama dan ilmu adalah jika agama dan mite "menyatukan" simbol dengan yang ditandai (signified), maka ilmu (seperti bahasa sehari-hari dan common sense) membedakan antara keduanya, dan dari pembedaan ini dihasilkan "sistem relasi" (Morris, 2003: 272).

Ada empat istilah yang terkait dengan persoalan ini: indeks, signal, icon, dan simbol. Indeks adalah sebuah tanda yang secara langsung berkaitan dengan apa yang ditandai, misalnya jejak kaki seekor singa. Tanda (signal) dianggap sebagai aspek dinamis dari indeks. Icon adalah tanda yang digunakan ketika ditafsirkan atau dimaksudkan adanya hubungan "persamaan-sensoris", misalnya patung seekor singa adalah iconic. Sementara simbol adalah sebuah tanda yang memiliki rangkaian hubungan yang kompleks, tetapi tidak ada hubungan langsung atau kesamaan antara tanda dan objek yang ditandai. Hubungan tersebut didasarkan pada konvensi dan nampak arbiter, misalnya singa adalah simbol keberanian (Morris, 2003: 273).

Berbeda dengan Cassirer, Edmund Leach melihat simbol dan tanda (signal) sebagai sub bagian dari indeks. Namun Leach menggunakan istilah "tanda" sebagai sebutan "simbol", di mana hubungan antara tanda dan sesuatu yang ditandai itu berdekatan. Bagi Leach, contoh sebuah tanda adalah mahkota yang menunjukkan kedaulatan. Leach membuat pembedaan analitis tersebut guna memberikan perangkat konseptual bagi analisa struktural terhadap sistem simbolik, yang meliputi: mite, magis, dan agama. Hubungan antara tanda dan simbol bersifat intrinsik dan metonomik, memiliki konteks kultural yang sama. Sebagaimana penjelasan Morris, Leach dalam konteks ini mencoba mengkombinasikan dua pendekatan, yaitu pendekatan sosio-struktural dan strukturalis.

Pendekatan sosio-struktural terhadap simbolisme yang menghubungkan 
simbol dengan kategori-kategori sosial tergambar jelas dalam tulisan Leach "Animal Categories and Verbal Abuse", di mana ia berusaha membongkar hubungan mendasar yang diekspresikan dalam metafor antara binatang dan kategori-kategori sosial. Menurut Leach, simbol tidak dapat dipahami secara terpisah dan tidak ada simbolisme universal, meskipun mungkin ada beberapa tema simbolik umum. Setiap simbol menurut Leach memiliki potensi polisemi, yang memiliki makna hanya ketika dipertentangkan dengan simbol-simbol lainnya sebagai bagian dari satu keutuhan. Maka untuk memahami simbolisme berarti harus mengeksplorasi secara detail konteks etnografik tertentu (Morris, 2003: 275-278).

Ada empat pendekatan dalam studi simbolisme, yaitu: pertama, pendekatan strukturalis. Pendekatan ini berusaha menggambarkan struktur formal atau pola-pola dasar yang berada dalam satu sistem simbol tertentu. Kedua, pendekatan sosio-struktural. Pendekatan ini memberikan prioritas teoretis kepada satu segi atau satu aspek sistem simbol, karena itu pendekatan ini menjadikan struktur sosial sebagai dasar dari berbagai kode simbolik. Ketiga, pendekatan yang berusaha menginterpretasikan makna-makna simbol melalui bentuk-bentuk arketip (archetype) alam bawah sadar (model Jung) atau dengan mengacu pada paradigma mitis pan-human (model Mircea Eliade). Keempat, pendekatan yang dikemukakan oleh Dan Sperber (Morris, 2003: 278-291) yang menegaskan, bahwa simbolisme paling baik dipahami bukan dari segi semiologi, tetapi sebagai mekanisme kognitif.

Simbol tidak sekadar kesederhanaan sebuah refleksi atas dunia alami sebagaimana yang telah kita lihat dalam hubungan dengan peristiwa-peristiwa alam, melainkan simbol juga merupakan refleksi dari kreativitas dan imajinasi manusia (Rennie, 1996: 58). Studi tentang manusia tidak saja bersifat historis, melainkan juga sebuah kehidupan simbol, sejarah tentang agama-agama yang bisa menjadi sebuah metapsiko-analisis. Dalam kasus pertama, simbol keagamaan dilihat sebagai yang penuh arti hanya dalam hubungannya dengan simbol lain dalam sistem budaya. Pada kasus kedua, arti dari simbol hanya bisa dijelaskan oleh komparasi dengan simbol sederhana dalam sebuah sistem simbol universal. Pendekatan kedua ini secara khusus didukung oleh Mircia Eliade.

\section{Aspek Simbolik dalam Ibadah Haji}

Ibadah haji dibawa oleh Ibrahim as sekitar 3.600 tahun lalus sesudah masa beliau praktik-praktiknya sedikit atau banyak telah mengalami perubahan, namun kemudian diluruskan kembali oleh Nabi Muhammad SAW .Salah 
satu yang diluruskan itu adalah praktik ritual yang bertentangan dengan penghayatan nilai kemanusiaan universal tersebut, Melalui al Quran, Allah SWT menegur sekelompok manusia (yang dikenal dengan nama al Hummas) yang merasa memiliki keistimewaan sehingga enggan bersatu dengan orang banyak dalam melakukan wukuf. Mereka tidak melakukan wukuf di Arafah sebagaimana yang dilakukan oleh Nabi dan sesuai syariat yang berlaku, melainkan wukuf di Muzdalifah. Pemisahan diri yang dilatarbelakangi oleh perasaan superioritas itu kemudian dicegah oleh al Quran dan turunlah ayat tersebut: "Bertolaklah kamu dari tempat bertolaknya orang-orang banyak dan mohonlah ampun kepada Allah. Sesungguhnya Allah Maha Pengampun lagi Maha Penyayang" (Shihab, 1992: 334).

Tidak jelas apakah praktik bergandengan tangan saat melaksanakan tawaf pada periode awal sejarah Islam bersumber dari ajaran Ibrahim as dalam rangka mempererat persaudaraan dan rasa persamaan. Namun, yang jelas Nabi SAW membatalkannya bukan dengan tujuan membatalkan persaudaraan dan persamaan itu, tetapi agaknya karena alasan-alasan praktis pelaksanaan tawaf.

Salah satu bukti yang jelas tentang keterkaitan ibadah haji dengan nilai-nilai kemanusiaan antara lain adalah adanya ajaran tentang: persamaan, keharusan memelihara jiwa, harta dan kehormatan orang lain, larangan melakukan penindasan atau pemerasan terhadap kaum lemah baik di bidang ekonomi maupun bidang-bidang lain. Tentu saja makna kemanusiaan dan pengamalan nilai-nilainya tidak hanya terbatas pada persamaan nilai kemanusiaan, ia mencakup seperangkat nilai-nilai luhur yang seharusnya menghiasi jiwa pemiliknya. Ia bermula dari kesadaran akan jatidiri (fithrah) serta keharusannya menyesuaikannya diri dengan tujuan kehadiran di pentas bumi ini. Kemanusiaan menjadikan makhluk ini memiliki moral serta berkemampuan memimpin makhluk-makhluk lain dalam mencapai tujuan penciptaan. Kemanusiaan mengantarkannya untuk menyadari bahwa ia adalah makhluk yang harus bertanggung jawab menjadi pemimpin sekaligus makhluk sosial yang tidak dapat hidup sendirian dan harus bertenggangrasa dalam berinteraksi.

Dalam khutbah haji Wada' Nabi menekankan akan pentingnya makna persamaan, keharusan memelihara jiwa, harta dan kehormatan orang lain, larangan melakukan penindasan atau pemerasan terhadap kaum lemah, baik dalam bidang ekonomi maupun bidang-bidang lainnya. Pandangan Nabi di atas telah menjadi bukti sejarah bahwa ada keterkaitan erat antara ibadah 
haji dengan nilai-nilai kemanusian universal.

Di balik doktrin-doktrin kemanusiaan ini, haji juga membawa pengalaman kemanusiaan yang luar biasa. Hal ini bisa dilihat dalam acara-acara ritual atau non-ritualnya, kewajiban-kewajiban atau larangan-larangannya, ajaran substansial maupun formalnya. Sebut saja misalnya, ditanggalkannya pakaian keseharian seraya mengenakan pakaian putih yang suci, dilarangnya melakukan pembunuhan baik terhadap binatang maupun tanaman, terlebih lagi terhadap manusia.

Disadari atau tidak, penanggalan pakaian di atas secara tidak langsung akan membuang sekat antara si kaya dan si miskin, dari sana tidak lagi dimungkinkan akan muncul perbedaan status sosial (the difference of social status). Itulah harapan ideal ajaran haji, yakni membuat pelakunya menyadari bahwa ia adalah makhluk sosial yang tidak mungkin hidup sendiri dalam berinteraksi.

Dengan demikian, haji merupakan ritus akbar yang sarat makna (Ciciek, 2001: 38). Padanya terdapat seperangkat aktivitas simbolik tentang perjalanan umat manusia menuju tingkat ketakwaan sejati. Haji adalah merupakan upaya pengejawantahan kesetaraan baik dalam persepsi teologis maupun sosiologis. Semua manusia bergerak seirama dan senada dalam posisi kemanusian yang sama. Tiada yang mulia maupun yang hina, karena yang ada hanyalah dua eksistensi, Tuhan dan manusia yang menyatu dalam sebuah momen ritual yang unik. Namun sayangnya, tradisi masyarakat yang sangat berlebihan dalam memuliakan para haji telah merubah substansi makna dan tujuan awalnya.

Syariat haji mengandung dimensi yang penuh simbol. Di antara aspek simbolik ibadah haji itu adalah sebagaimana berikut (Shihab, 1992: 35):

Pertama, ibadah haji dimulai dengan berihram, dengan niat menanggalkan pakaian biasa dan mengenakan pakaian ihram. Tidak dapat disangkal bahwa pakaian menurut kenyataannya dan juga menurut al Quran berfungsi antara lain, sebagai pembeda antara seseorang atau sekelompok dengan lainnya. Pembedaan tersebut dapat membawa antara lain kepada perbedaan status sosial, ekonomi, atau profesi. Pakaian juga dapat memberi pengaruh psikologis kepada pemakainya.

Di Miqat Makani, tempat ritual ibadah haji dimulai, perbedaan dan pembedaan tersebut harus ditanggalkan, sehingga semua harus memakai pakaian yang sama. Pengaruh-pengaruh psikologis yang negatif dari pakaian pun harus ditanggalkan sehingga semua merasa dalam satu kesatuan dan persamaan.

el Harakah Vol.15 No.2 Tahun 2013 
Di Miqat, dengan mengenakan dua helai pakaian berwarna putih-putih sebagaimana yang akan membalut tubuh ketika mengakhiri perjalanan hidup di dunia ini, seseorang yang melaksanakan ibadah haji seharusnya dipengaruhi oleh pakaian ini. Seharusnya ia merasakan kelemahan dan keterbatasannya serta pertanggungjawaban yang akan ditunaikannya kelak di hadapan Tuhan Yang Mahakuasa, yang di sisi-Nya tiada perbedaan antara seseorang dengan yang lain kecuali atas dasar pengabdian dan ketakwaan kepada-Nya.

Kedua, dengan dikenakannya pakaian ihram, maka sejumlah larangan harus diindahkan oleh pelaku ibadah haji, misalnya dilarang menyiksa binatang, membunuh, menumpahkan darah, mencabut pepohonan, dan lain sebagainya. Mengapa? Karena, manusia berfungsi memelihara makhlukmakhluk Tuhan serta memberinya kesempatan seluas mungkin untuk mencapai tujuan penciptaannya. Dilarang juga menggunakan wangi-wangian, bercumbu atau kawin, dan berhias supaya setiap jama'ah haji menyadari bahwa manusia bukan materi semata-mata, bukan pula nafsu birahi; dan bahwa hiasan yang dinilai Tuhan adalah hiasan ruhani. Dilarang pula menggunting rambut dan kuku supaya masing-masing menyadari jati dirinya dan menghadap kepada Tuhan sebagaimana apa adanya.

Ketiga, Ka'bah yang dikunjungi mengandung pelajaran yang amat berharga dari segi kemanusiaan. Di sana, misalnya, ada Hijr Ismail yang arti harfiahnya "pangkuan Ismail”. Di sanalah Ismail, pembangun ka'bah ini, pernah berada dalam pangkuan ibunya yang bernama Hajar, seorang wanita hitam, miskin bahkan budak, yang konon kuburannya pun berada di tempat itu. Namun demikian, budak wanita ini ditempatkan Tuhan di sana (atau peninggalannya diabadikan oleh Tuhan) untuk menjadikan pelajaran bahwa Allah SWT memberikan kedudukan untuk seseorang bukan karena keturunannya atau status sosialnya, tetapi karena kedekatannya kepada Allah SWT dan usahanya untuk berhijrah dari kejahatan menuju kebaikan, dari keterbelakangan menuju peradaban.

Keempat, setelah selesai melakukan tawaf -yang menjadikan pelakunya larut dan berbaur besama manusia-manusia yang lain, serta memberikan kesan kebersamaan menuju satu tujuan yang sama, yakni berada dalam lingkungan Allah SWT- dilakukanlah sa'i. Di sini muncul lagi Hajar, budak wanita bersahaja yang diperistri nabi Ibrahim as. Diperagakan pengalamannya mencari air untuk putranya.

Keyakinan wanita akan kebesaran dan kemahakuasaan Allah SWT itu sedemikian kokohnya terbukti jauh sebelum peristiwa pencarian itu, yakni 
ketika ia bersedia ditinggal bersama anaknya di suatu lembah yang tandus. Keyakinannya yang begitu dalam tidak menjadikannya berpangku tangan dengan hanya menunggu turunnya hujan dari langit, tetapi ia berusaha mondar-mandir berkali-kali demi mencari kehidupan.

Hajar memulai usahanya dari bukit Shafa) yang arti harfiahnya adalah kesucian dan ketegaran,(sebagai lambang bahwa untuk mencapai hidup harus di mulai dengan usaha dengan kesucian dan ketegaran dan harus diakhiri di Marwa-yang berarti" ideal manusia."Adakah makna yang lebih agung berkaitan dengan pengamalan kemanusiaan dalam mencari kehidupan duniawi melebihi makna-makna yang digambarkan di atas?

Kalau tawaf menggambarkan larut dan meleburnya manusia dalam hadirat Ilahi atau dalam istilah kaum sufi disebut al fana' fillah, maka sa'i menggambarkan usaha manusia mencari hidup yang melambangkan bahwa kehidupan dunia dan akhirat merupakan suatu kesatuan dan keterpaduan. Dengan tawaf disadari tujuan hidup manusia dan menggambarkan bahwa tugas manusia adalah berupaya semaksimal mungkin. Hasil usaha pasti akan diperoleh baik melalui usahanya maupun melalui anugerah Tuhan, seperti yang dialami oleh Hajar a.s. bersama puteranya, Ismail, dengan ditemukannya air zamzam itu.

Kelima, di Arafah, padang yang luas lagi gersang itu, seluruh jamaah wukuf (berhenti) sampai terbenamnya matahari. Di sanalah mereka seharusnya menemukan manusia yang mengetahui tentang jatidirinya, akhir perjalanan hidupnya, serta di sana pula ia menyadari langkah-langkahnya selama ini. Di sana pula seharusnya ia menyadari betapa besar dan agung Tuhan yang kepada-Nya menyembah seluruh makhluk sebagaimana diperagakan secara miniatur di padang Arafah tersebut.

Keenam, dari Arafah, para jamaah menuju Muzdalifah untuk mengumpulkan batu-batu kerikil dalam menghadapi musuh utama yaitu syetan, kemudian melanjutkan perjalanan ke Mina dan di sanalah para jamaah haji melampiaskan kebencian dan kemarahan mereka masing-masing terhadap musuh yang selama ini menjadi penyebab segala kegetiran yang dialaminya. Batu dikumpulkan di tengah malam sebagai lambang bahwa musuh tidak boleh mengetahui siasat kita. Demikianlah ibadah haji merupakan kumpulan simbol-simbol yang sangat indah. Apabila dihayati dan diamalkan secara baik dan benar, maka pasti akan mengantarkan setiap pelakunya ke dalam lingkungan Ilahi dan kemanusiaan yang benar sebagaimana dikehendaki oleh penciptanya, Allah SWT. 


\section{Haji dalam Perspektif Masyarakat Muslim}

Dalam teori sosiologi dinyatakan bahwa setiap masyarakat pasti memiliki sesuatu yang dihargai, merupakan bibit yang dapat menimbulkan adanya sistem berlapis-lapis dalam masyarakat. Sementara itu juga ditegaskan bahwa dalam sistem sosial terdapat dua pemilahan status, pertama adalah achieved status (yang dapat dicapai oleh setiap orang dengan usaha-usaha yang disengaja); kedua, ascribed status (hanya dapat dicapai berdasarkan kelahiran). Haji dalam hal ini masuk dalam kategori pertama, yang terbuka kemungkinan bagi setiap orang untuk mencapainya (Sumardjan dan Sumardi, 1964: 253, 263).

Fenomena sosiologis di atas dapat dibuktikan oleh betapa kuatnya sebagian masyarakat tertentu dalam berusaha memperoleh capaian ibadah haji dimaksud $(\mathrm{ONH})$, misalnya dengan menjual sawahnya (yang sering disebut dengan haji "wahyu", karena sawahnya payu (Jw.), menjual tambaknya (yang dikenal dengan sebutan haji "mbakyu", karena tambaknya payu), melalui sokongan orang banyak (yang dikenal dengan haji "sokeh", sokongan wong akeh), dan seterusnya.

Dengan begitu jika teori sosiologi ini dihubungkan dengan fenomena haji, maka sepanjang suatu masyarakat memandang pelaksanaan ibadah haji sebagai sesuatu yang berharga dan istimewa, sepanjang itu pula masyarakat akan menempatkan para haji berada pada lapisan yang relatif lebih tinggi.

Penelitian menunjukkan adanya kekuatan peran haji di kalangan orang Jawa, dan mereka menjadikan Makkah sebagai legitimasi kekuasaan atau keilmuan seseorang (Van Bruinessen, 1991: 122). Penilaian orang Jawa yang begitu tinggi terhadap Makkah sebagai pusat spiritual tidak terbatas pada kalangan santri saja. Namun satu hal yang menarik, menurut Van Bruinessen, orang-orang Jawa juga menganggap Jawa (Indonesia) juga sebagai pusat kosmis selain Makkah. Beberapa daerah di Indonesia ada tempat yang oleh masyarakat sekitarnya dianggap setaraf Makkah sebagai pusat kosmis, misalnya adanya kepercayaan bahwa tiga kali naik Gunung Ciremai pahalanya sama dengan naik haji. Di Madura juga ada kepercayaan bahwa bagi yang tidak mampu naik haji, ziarah ke Batu Ampar akan mendatangkan pahala yang sama, di Sulawesi Selatan ada kepercayaan bahwa naik gunung Bawa Karaeng pada hari Idul Adha sama dengan naik haji ke Makkah.

Demikian juga anggapan tentang Keraton Yogyakarta sebagai pusat kosmis, dimana arsitektur dan ikonografinya yang sangat kompleks menyimbolkan eksplanasi-eksplanasi sufi mengenai siklus kehidupan, hubungan jalan mistik antara Allah SWT dan manusia serta antara kesalehan normatif dan doktrin 
mistik juga (Woodward, 1997: 123-124).

Dalam konteks status sosial, haji tidak sekadar memiliki makna sebagai doktrin keagamaan semata, tetapi telah mengalami perluasan persepsi sebagai institusi yang mampu menjaga nilai-nilai lokal (Farida, 1999: 37-38). Sebagai doktrin sosial, haji juga telah menyediakan seperangkat pranata yang dapat menaikkan status sosial dalam masyarakat. Hal ini terjadi pada masyarakat pedagang Betawi. Pilihan yang paling populer di kalangan pedagang yang ingin naik status sosialnya adalah dengan berhaji. Terlepas dari apakah gelar tersebut terkait dengan kualitas keberagamaan mereka atau tidak. Pada masyarakat pedagang Betawi, haji mampu meningkatkan status sosial sejajar dengan elit keagamaan lainnya, seperti kiai atau ulama. Gelar "haji" juga memberikan legitimasi "logika keagamaan" untuk memiliki istri lebih dari satu. Di pihak perempuan, diperistri oleh seorang haji juga telah menaikkan status sosial mereka, terlepas apakah dijadikan sebagai istri kedua atau pertama.

Sebagian besar masyarakat pedesaan Madura menganggap ibadah haji merupakan bagian dari cita-cita hidup mereka (Madani, 1984: 30) Oleh sebab itu, terkurasnya sedemikian besar harta untuk biaya haji tidak akan menyebabkan jatuh pailitnya seorang haji.

Penelitian di Kabupaten Malang juga menunjukkan hasil yang serupa, bahwa ibadah haji di kalangan masyarakat petani santri Gondanglegi merupakan ibadah yang istimewa dan memiliki daya tarik yang luar biasa (Zainuddin, 2002: 63-83). Ada persepsi umum di kalangan mereka bahwa "haji membuat orang menjadi kaya. Harta yang digunakan untuk berhaji tidak pernah akan habis". Persepsi demikian ternyata tidak dijumpai pada aktivitas ibadah yang lain, misalnya, "harta atau uang tidak akan pernah habis untuk dikeluarkan zakatnya", atau untuk biaya pendidikan dan seterusnya. Bahkan menurut mereka, meski jadi sopir dan tidak sekolah tidak jadi masalah asal mereka sudah melaksanakan haji.

Pada umumnya persiapan untuk pergi haji bagi kebanyakan masyarakat muslim sangatlah istimewa, mulai dari selametan, menyediakan oleh-oleh untuk para tetangga dan para tamu sampai pada acara-acara ritual-seremonial yang lain. Demikian pula acara penyambutan keberangkatan maupun kepulangan. Pada saat upacara keberangkatan, penghormatan terhadap para calon jemaah haji nampak semakin semarak. Iring-iringan mobil yang mengantarkan mereka menuju ke embarkasi atau tempat keberangkatan lainnya menambah sakralnya peribadatan tersebut. Demikian pula ketika mereka kembali pulang dari tanah suci, suasana yang sama juga mewarnai kehidupan keagamaan itu. 
Di kalangan masyarakat muslim Madura -dan juga sebagian Jawaada tradisi mengganti nama lama menjadi baru yang diberikan oleh seorang Syeikh di Makkah. Penggantian nama ini bagi masyarakat pedesaan Madura seolah-olah merupakan keharusan, misalnya dari nama Kailan, setelah pulang dari haji diganti dengan Abdussyakur. Nama yang terakhir inilah kemudian yang populer dan dipopulerkan di masyarakat (biasanya kemudian disingkat menjadi Haji Syakur, Kang Kaji dan seterusnya). Sebaliknya, sesuatu yang dianggap tidak lazim dan tidak sopan apabila setelah itu masih ada orang yang memanggilnya dengan nama dan panggilan lama (sebelum haji), kecuali bagi orang yang tidak tahu atau belum mengenalnya. Oleh sebab itu, atribut haji (seperti songkok putih, serban dan lain-lain) harus dipakai.

Ibadah haji di sini dianggap sebagai transisi menuju status baru. Bagi seorang santri remaja, ibadah haji dianggap sebagai penutup ideal setelah pendidikan di pesantren dan sekaligus sebagai awal masa dewasa. Bila keluarga seorang santri menganggap pendidikan anaknya di pesantren sudah selesai, maka mereka kemudian mengusahakan anaknya menjalankan haji ke Makkah. Sekembalinya dari sana bisanya diberi julukan Haji X. Ibadah haji di sini kemudian dipersepsi sebagai transisi menuju satus baru dengan nama baru yang dipilih di Makkah (Vandenbregt, 1991: 44-45).

Melalui kajian biografi Muhammad Radjab, tokoh penting Minangkabau, Vedenbregt mengatakan bahwa martabat tinggi yang dimiliki seorang haji di sana menyebabkan banyak anak muda ingin melaksanakan ibadah haji; mereka belajar agama dengan tekun. Sekembalinya dari Makkah mereka melengkapi diri dengan serban dan simbol-simbol haji lainnya dan mulai saat itu mereka pasti akan dilamar untuk dinikahkan. Kebiasaan untuk memilih nama baru di Makkah yang diikuti oleh banyak jamaah haji mempertegas transisi ke suatu kurun waktu hidup baru, yang kebiasaan ini sesuai dengan kebiasaan orang Indonesia yang memilih nama baru bila mencapai kurun waktu hidup yang penting atau setelah menderita sakit yang parah untuk waktu yang lama (Vandenbregt, 1991: 44-45).

Salah satu indikasi naiknya status sosial para haji pada masyarakat pedesaan Madura nampak pada perlakuan terhadap mereka, khususnya dalam upacara-upacara berbau keagamaan. Dalam acara-acara semisal tahlilan (doa bersama atau kirim doa untuk arwah orang yang sudah meninggal), haul (peringatan tahunan untuk sesorang yang meninggal), walimahan (baik walimah nikah maupun walimah pemberian nama anak, walimah tasmiyah) dan seterusnya, para haji biasanya ditempatkan pada posisi terdepan sejajar 
dengan kiai atau bindharah (putera kiai), Gus (di Jawa). Hal yang demikian ini seolah-olah sudah menjadi konsensus di masyarakat tanpa mendatangkan kecemburuan sosial. Bagi masyarakat pedesaan Madura, menaiknya status sosial haji ini juga memiliki pengaruh terhadap keluarga. Semakin besar jumlah para haji dalam satu keluarga, maka semakin kukuh dan besar pula statusnya di mata masyarakat. Istilah bala keraba (keluarga kuat) merupakan istilah yang sarat makna keagamaan, di mana mereka terdiri dari keluarga para haji (Madani, 1984:30). Persoalan ini juga bisa dimaklumi jika ditinjau dari perspektif ekonomi. Sebab bagi orang yang bisa pergi haji secara otomatis mereka berkecukupan secara materi. Dengan demikian, seseorang yang telah haji sesungguhnya juga identik dengan wong sugih, wong duwe (the have) dan berkecukupan.

Bagi masyarakat muslim pada umumnya, penghormatan untuk para jamaah haji diselenggarakan melalui upacara walimat al safar. Upacara yang penuh nuansa ritus dan sakral ini biasanya dilakukan tujuh hari sebelum calon haji memasuki asrama haji. Acara dipimpin oleh seorang ulama lokal (kiai). Diawali dengan pembacaan fatihah yang pahala bacaannya dikirimkan untuk Rasulullah SAW, keluarga, para sahabat dan seluruh pengikutnya dan dirangkai dengan ratib Hadad; dikumandangkan azan dan sebagainya. Upacara juga diisi dengan ceramah agama yang berisi nasihat-nasihat dan pesan-pesan haji. Acara tersebut juga dijadikan momentum permintaan maaf calon haji dengan sanak keluarga dan para tamu yang hadir, karena keberangkatan haji juga dipahami sebagai ibadah yang mempertaruhkan jiwa dan raga, pasrah untuk dipanggil oleh Allah SWT di sana (Makkah dan Madinah). Bahkan ada sebagian mereka yang minta mati di sana, karena menurut kepercayaan mereka, mati di sana lebih mulia dan dijamin masuk surga. Biasanya permintaan mati di sana berlaku bagi orang yang sudah tua (Farida, 1999: 34).

Haji di kalangan masyarakat muslim juga dipahami sebagai media "pembuktian" atas amal baik dan buruk sebelumnya. Pemahaman itu berkembang dari pengalaman keagamaan (religious experiences) yang diperoleh para jamaah haji selama mereka berada di tanah suci, Makkah. Bagi mereka yang sebelumnya berperilaku kurang terpuji, selama prosesi ibadah haji berlangsung, mereka akan mengalami kesulitan, misalnya: kehilangan barang, kesasar, diinjak-injak dan dipukuli orang dan sebagainya yang selalu dikaitkan dengan perilaku buruk sebelum haji. Sebaliknya, bila seseorang yang banyak memperoleh pertolongan dan kemudahan-kemudahan di sana (Makkah) serta merta diklaim sebagai ganjaran atas perbuatan kebajikan 
sebelumnya. Bahkan bagi orang yang di sana mendapat kesulitan, diklaim sebagai "orang yang kualat" atas perbuatannya selama ini (sebelum haji). Di sinilah kemudian yang kadang-kadang juga memunculkan "kekhawatiran" sebagian orang muslim untuk berangkat haji, takut jika "kualat". Makkah diasumsikan sebagai "miniatur akhirat" karena di situ ditunjukkan azab dan ganjaran. Di sinilah upacara keagamaan keberangkatan haji menjadi relevan untuk ditelaah melalui perspektif "doktrin" ini.

Tidak jauh berbeda dengan penyambutan keberangkatan haji, kepulangan jamaah haji juga disambut dengan upacara yang hampir sama, yang disebut dengan "tasyakuran haji", karena mereka bersyukur bisa selamat dari berangkat hingga pulang. Pada saat seperti inilah, mereka banyak menerima tamu yang meminta oleh-oleh "berkah haji", terutama yang terkait dengan pelaksanaan haji. Dan pada umumnya "haji baru" memberikan oleh-oleh yang berupa peralatan shalat, seperti: tasbih, kopiah haji, kerudung, sajadah, air zamzam, dan sebagainya. Mereka banyak yang bertanya soal keadaan di sana, mulai dari kondisi udara, sampai pada pengalaman-pengalaman keagamaan yang bersifat "khusus" (religious experiences). Bagi tamu yang sudah haji, mereka banyak membandingkan dan konfirmasi, sementara bagi yang belum haji banyak mendengarkan cerita "pak Haji baru" itu.

"Memperoleh berkah haji”, demikian kepercayaan umum di kalangan masyarakat muslim. Mereka mempunyai kepercayaan, bahwa seseorang yang baru datang dari tanah suci, diri dan tempat tinggalnya dijaga oleh 40 malaikat yang senantiasa menjaga kerahmatan Allah SWT. Oleh sebab itu, sebagian mereka ada yang tidak keluar rumah (bepergian) sebelum genap 40 hari tersebut (Farida, 1999: 34). Di sini pula "haji baru" selalu dimintai berkah doanya. Sebelum pamit pulang para tamu selalu meminta berkah doa karena adanya kepercayaan di atas.

Dalam konteks relasi simbolik agama dengan status sosial ini, penelitian Madani (1984: 29) menunjukkan bahwa persepsi masyarakat Madura terhadap ibadah haji dan cara pemikiran mereka yang sederhana memungkinkan para haji memperoleh status sosial sebagai orang yang berada pada lapisan atas dalam masyarakat. Akan tetapi, apabila terjadi pergeseran persepsi dan pola pikir, maka status sosial tersebut tidak akan diperoleh lagi oleh para haji, sebagaimana yang terbukti pada para haji di kalangan masyarakat perkotaan.

\section{Simpulan}

Secara normatif, pesan ibadah haji sebenarnya mengandung nilai-nilai 
ajaran sosial yang tinggi, seperti menjauhkan sekat antara si kaya dan si miskin, menjauhkan perbedaan status sosial (the difference of social status). Itulah harapan ideal ajaran haji, yakni membuat pelakunya menyadari bahwa ia adalah makhluk sosial yang tidak mungkin hidup sendiri dalam berinteraksi.

Dalam persepsi masyarakat muslim, baik di Jawa maupun di luar Jawa, ibadah haji sarat dengan simbol-simbol dan status, baik status sosial maupun terkait dengan status legitimasi kekuasaan. Haji lebih dipahami sebagai sebuah simbol keagamaan yang sarat dengan nilai-nilai justifikasi sosial dan kultural ketimbang sebagai ibadah yang berdimensi kemanusiaan universal: egaliter, toleran, ukhuwwah, persatuan dan kesatuan, tanggungjawab, santun dan sabar sebagaimana yang tercermin dalam pelaksanaan ihram, tawaf, sa'i, wukuf, dan seterusnya.

Ibadah haji di kalangan masyarakat muslim dipahami sebagai achieved status, yang dapat dicapai oleh setiap orang melalui usaha keras. Dengan begitu jika teori sosiologis ini dihubungkan dengan fenomena haji, maka sepanjang suatu masyarakat memandang pelaksanaan ibadah haji sebagai sesuatu yang berharga dan istimewa, sepanjang itu pula masyarakat akan menempatkan para haji berada pada lapisan yang relatif lebih tinggi.

\section{Daftar Pustaka}

Departemen Agama RI. 1992. Al Quran dan Terjemahannya, Jakarta: Departemen Agama RI.

Dillistone, F.W. 2002. The Power of Symbols (terj). Yogyakarta: Kanisius.

Farida, Anik. 1999. "Haji dalam Stratifikasi Sosial Masyarakat Betawi Pedagang di Kelurahan Jombang, Jakarta Selatan”. Dalam Penamas, Nomor 33, Tahun XII: 33-38.

Harian Kompas, 3/3/2001.

Madani, Malik. 1984. "Citra Status Sosial Para Haji di Kalangan Masyarakat Pedesaan Madura” dalam Al Jamiah, 1985, IAIN Sunan Kalijaga Yogyakarta: Vol. 8.

Maliki, Zainuddin. 2002. "Agama dan Kekuasaan: Studi Penggunaan Simbolsimbol Agama Sebagai Sarana Kekuasaan Elit Jawa Masa Kini di Kota Surabaya”. [disertasi Universitas Airlangga]

Minsarwati, Wisnu. 2002. Mitos Merapi dan Kearifan Ekologi. Yogyakarta:

el Harakah Vol.15 No.2 Tahun 2013 
Kreasi Wacana.

Morris, Brian. 2003. Antropologi Agama: Kritik Teori-Teori Agama Kontemporer. Yogyakarta: AK. Grup.

Rennie, Brian S. 1996. Reconstructing Eliade: Making Sense of Religion. New York: State University of New York Press.

Sumardjan, Selo dan Soelaiman Sumardi. 1964. Setangkai Bunga Sosiologi. Jakarta: Lembaga Penerbitan Fakultas Ekonomi Universitas Indonesia.

Shihab, Quraish. 1992. Membumikan al Quran. Jakarta: Mizan.

Vandenbregt, Jacob. 1991. "Ibadah Haji: Beberapa Ciri dan Fungsinya”. Dalam Dick Dowes dan Nico Kaptein. Ibadah Haji di Indonesia. Jakarta: INIS.

Van Bruinessen, Martin. 1991. "Mencari Ilmu dan Pahala di Tanah Suci: Orang Nusantara Naik Haji”. Dalam Dick Dowes dan Nico Kaptein. Ibadah Haji di Indonesia. Jakarta: INIS

Woodward, Mark R. 1990. Islam Jawa: Kesalehan Normatif versus Kebatinan. Yogyakarta: LKiS.

Zainuddin, M. 2002. Fenomena Haji di Kalangan Petani Santri di Gondanglegi. [laporan penelitian DIK]. Malang: STAIN Malang. 